\title{
On International Protection Of Minorities; Aspects Of Minorities Protection By Albanian Legislation
}

\author{
Dr. Senada Reci \\ University "Luigj Gurakuqi”, Shkoder, Albania
}

MSc. Luljeta Zefi

Notary assistant at the Chamber of Notaries, Shkoder, Albania

doi: 10.19044/esj.2016.v12n8p258 URL:http://dx.doi.org/10.19044/esj.2016.v12n8p258

\begin{abstract}
Minorities are part of the people living in a country and being not part of the majority of the population, always have problems relating to the implementation of the rights and fundamental freedoms to them. Filling this vacuum is internationally seen the Framework Convention for the protection of minorities, which sets targets to be achieved by States and its implementation is provided primarily by the measures taken on the national law and secondarily by bilateral agreements since its provisions are not directly applicable. There are also some other international acts of the Council of Europe that sanction rights for minorities. But this paper devotes attention to Albanian legislation and its commitments to enforce the rights and protection of minorities, especially in the context of the integration process in the EU, where the approach of the standards of the acquis for minorities is the focus of monitoring alongside the fundamental human rights and freedoms from the European Commission. EC has introduced the issue of minorities in the Albanian legislation with problems and situation outside the framework of legal protection because of the vacuum of a legal act for minorities, and this paper aims to present some aspects of the problem reflected in its analysis.
\end{abstract}

Keywords: Minorities, Framework-convention, Council of Europe, fundamental rights and freedoms

\section{Introduction}

Minorities are a vulnerable target group for their rights and fundamental freedoms throughout the European continent and beyond it. Various European legislations efforts to secure the minority rights of its citizens were not efficient till the exit of the Framework Convention for the protection of minorities. Creation of a special convention on the protection of 
national minorities had the initiative in Vienna in 1993.

The Committee of Ministers of the Council of Europe established an ad hoc committee for the protection of national minorities by giving priority to the processing of the Framework Convention, which estimated that an agreement on the content of the rights that needed to be recognized to minorities would be achieved more quickly. Since it was a Convention which would not be prejudiced by the defense mechanism of these rights, the protocol was subjected to judicial control provided by the ECtHR. The Committee of Ministers, after examining some contradictory points adopted in 1994 and approved this draft Framework Convention on National Minorities which entered into force in February 1998, after twelve Member States of the Council of Europe expressed their consent (In September 1995, 27 countries signed the Outlined Convention and two countries ratified it. Andorra, Bulgaria, France, Greece, Luxembourg and Turkey did not sign the Convention).

\section{Framework Convention for minorities and its legal effects}

Framework Convention for minorities announces in a certain number of provisions the objectives to be achieved by States, and its implementation is provided primarily by the measures taken on the national law and secondarily by bilateral agreement since the provisions were not directly applicable. States have a wide margin of appreciation to adapt their legislation to peculiarities of minorities living in their territory. Also, the Framework Convention is composed of a certain number of rights guaranteed by the ECHR, to be implemented by signatory states. The Framework Convention reiterates a certain number of principles regarding the promotion of identities of national minorities always respecting the priority of law, territorial integrity and the sovereignty of states, the purpose of this was to leave to the states depending on the particular characteristics of minorities to choose themselves additional actions to be taken.

The Convention represents the highest level of commitments that countries should take on the protection of minorities. Committee of experts in charge of drafting the convention faced some difficulties, starting with the definition itself of the national minority, avoiding the definition of the concept of national minority. Given the difficulties encountered in finding such meaning that could include all categories of minorities, the lack of a general definition did not constitute an obstacle to the implementation of rules promulgated by the convention. It was better preferred to use the expression "national minority", rather than to identify the differences through ethnic, religious or linguistic minority. The downside of the lack of a definition of national minorities lies in the fact that it remains the Member States to recognize an individual group as a minority with its order to apply a 
protective regime of the Convention.

By itself the freedom that gives Framework Convention to the Contracting States (somehow lack of consensus to conceive this freedom is an indicative fact that states do not want to intervene in internal situations to each other cause of the delicate issue of minorities and decided to manage each according to national circumstances and respecting protection of minorities) understand the different margins evaluation by them in respect of measures against minorities.

\section{Non-recognition of the collective rights}

Framework Convention does not provide collective minority rights exercised by the entirety of the minority group. This solution is explained by fears that such recognition could turn into a rigid support for the claims breakaway. The Framework Convention specifies that persons belonging to national minorities may exercise both individually and together with others the rights and freedoms arising from the principles outlined in this Convention (Explanatory Report of the experts underlines application of joint exercise of these rights and freedoms is something quite different from the notion of collective rights).

\section{Individual rights formulated as obligations to states}

Obligations that have been set to states in the Framework-Convention are intended not only to allow persons belonging to minorities to enjoy a freedom from which can benefit the rest of the population but require them to take measures involving positive action in the financial field, to ensure the effectiveness of these rights.

The Framework Convention implies the possibility that states translate the provisions of this Convention, based on the particular situation of their country, as well as appropriate legislation and government policy. This does not remove the obligation that no legal character.

The Convention is one of the most comprehensive treaties designed to protect the rights of persons belonging to national minorities. Parties to this Convention shall take the commitment to ensure full equality and efficiently to people who belong to minority groups, in all economic, social, political and cultural spheres as well as conditions that will also allow them to express, preserve and develop culture and identity (Minorities and protection of their rights in Albania, Albanian Center for Publication of Human Rights, 2008: p.9). Determined to implement the principles laid down in the Convention on national legislation and government policies, the parties agreed to sign the most important international document to protect the rights of minorities. 


\section{Protection of Minority Rights in the framework of legal documents to the CoE}

Despite the majority of legal texts on the rights of minorities, none of them has given a definition of the term "minority", or given general definitions hinder the implementation of the rights belonging to such groups, or go so far as to provide intermediate states determine on their own what constitutes a minority group.

Ex. France agrees that there are no minorities, although is a member of the EU and has in its population more religious, linguistic, ethnic, minorities. Although we have not a literal definition of the term "minority" is has been concluded this group to be regarded as such should contain the following features (Prof. Francesco Capotorti, Special Raporteur for minority rights)

-To be resident in the territory of a state and its citizen;

-To be resident in the territory of a country or to be sustainable and with historical links with the country concerned and be its citizen features

-To present the distinguishing ethnic, cultural, religious or linguistic

-Sufficient to be representative although smaller in number than the rest of the population

-To be motivated and interested to preserve together what constitutes their common identity, including their culture, traditions, religion or language.

The rights of minorities implicitly protected by Article 14 of the ECHR provides that: The enjoyment of the rights and freedoms set forth in this Convention shall be secured without discrimination on any ground such as sex, race, colour, language, religion, political or other opinion, national or social origin, association with a national minority, property, birth or another status.

The enjoyment of the rights and freedoms outlined in this Convention shall be secured without discrimination on any ground such as sex, race, color, language, religion, political or other opinion, national or social origin, association with a national minority, property, birth or another status.

From this article, we understand that all are equal before the law and entitled to the equal protection of the law without distinction regardless of whether or not a minority, they should be treated like the rest of the population.

The International Covenant on Civil-Political Rights in its composition has established a special section for minorities, which explicitly states: In states where there are ethnic, religious, or linguistic persons belonging to national minorities can not be deprived of the right to have, together with other members of the group itself, the life of its particular 
cultural background, to preach and to practice their religion or to use their language (Article 27, International Covenant on Civil Political Rights).

Unlike the ECHR, which in its composition does not have a separate article to define and to directly protect minority rights, we note that the International Covenant on Civil Political rights supporting the convention has reserved space for minority groups. Specifically, Article 27 thereof, oblige signatory states to protect their rights and to give the possibility to preserve and develop the characteristics and specifics that have these minority groups that differ from the rest of the population.

\section{Volume of minority rights (in view of individual rights)}

Signatory states that have agreed on the need to protect minorities, they still have not reached a consensus on the scope of the rights that will be familiar to them. Internal legislations vary from one country to another (F. Benoit-Rohmer, 2007: p. 50). Fundamental rights of minorities can be listed as follows:

a. Equality of rights of a minority to the rights of the majority population and equal protection before the law, but only equality before the law is not enough to safeguard the minority features. Therefore, the parties are committed to taking, if necessary, to promote positive measures in all areas (The ethnic and community relations in Europe, 1995: p. 36). For this purpose, the members of that right may be recognized minority rights supplementary to achieve a real and practical equality between minorities and the rest of the population without considering these rights as discrimination against the majority population (The ethnic and community relations in Europe, 1995).

b. Freedom of association, expression, thought, conscience and religion, these freedoms have a universal character they apply to all persons, regardless of whether they belong or not a vulnerable national minority, but they are particularly necessary for the protection of national minorities.

c. Freedom to use the minority language, Article 10 of the Framework Convention impose an obligation on parties to recognize every person belonging to national minorities the right to use freely and without hindrance minority language in private life as well as public orally and in writing. The right to learn the minority language is considered essential to maintaining the features of linguistic minorities (Article 14 of the Framework Convention for the protection of national minorities).

d. The right to education in the official language of the state combined with language learning another language is an obligation that States shall provide to protect minority groups. As regards freedom of education, Convention recognizes that persons belonging to national minorities have the right to establish and administer their private institutions of education and 
training provided that they are included in the framework of the educational system of the Contracting Parties (Article 13 of the Framework Convention for the protection of national minorities).

e. The right to property, States which have ratified the Convention are obliged to ensure minority groups the right of ownership without any discussion as well as the rest of the population.

f. The right of participation of minorities in public and economic life consists in the possibility that any entity minority have the right to participate actively in policy making and the economic and financial benefits.

\section{The space of minority rights in the Albanian legislation}

Albania has had and continues to have a permanent commitment regarding continuous improvement of the standards related to the protection and respect of human rights and fundamental freedoms, part of which are minority rights. The Albanian state has been one of the signatories of the unilateral and voluntary declaration of minority protection regime since the Geneva Declaration of Fan Noli (Central State Archive Fund: Ministry of Interior, 2007: p.2-3). The contents of the signed statement were reflected in "Basic Statute" of the state in the form of human rights, without specifying anything for minorities.

After the end of II World War, Albania has declared a People's Republic. And in these conditions, in the international context, Albania signed a statement regarding the rights of citizens or their social structure, such as that by ethnicity. The same situation continued with the adoption of the Constitution of 1976, and until the adoption of new principles of the Constitution of 1998.

Article 3 of the Convention corresponds to Article 20 of the Constitution of the Republic of Albania also elaborated in two paragraphs as follows:

1 Persons belonging to national minorities exercise in full equality before the law their rights and freedoms.

2. They have the right to express freely, without prohibition or compulsion, their ethnic, cultural, religious and linguistic belonging.

They have the right to preserve and develop them, learn and be taught in their mother tongue, as well as unite in organizations and associations to protect their interests and their identity.

As seen in the Albanian legislation, paragraph 1 of Article 20 of the Constitution does not have a separate definition of the term "national minority." The Constitution of the Republic of Albania has adopted the same expression in the relevant international instruments, in particular in Article 3 of the Convention (Article 3 of the Framework Convention for the protection of national minorities "every person belonging to a minority shall 
have the right to freely choose to be treated or not as such, and there will be no disadvantage from this choice or from the exercise of the rights associated with this choice). Article 18 of the Convention states that: "It is the duty of the neighboring countries to make joint efforts to create favorable conditions for the protection of minority rights falling within their territory." Parties shall endeavor to conclude, where necessary, bilateral and multilateral agreements with other states, especially with neighboring countries to ensure the protection of persons belonging to national minorities concerned.

In this regard, it is noteworthy Treaty of friendship, cooperation, good neighborly relations and security concluded between the Republic of Albania and the Republic of Greece on 21 March 1996 (A.Puto, Public International Law, 2004: p. 230).

The status and the situation of the Greek minority population in the south of the country has been objects of frequent contacts between the two parties. Unlike in the past when the matter dealt with often caused conflict in the relations between them. Minorities in Albania have the possibility of using their native language as well as their other rights. They have the right to establish political and cultural associations, political parties, the broad education in mother-tongue (V.Bici, The issue of bilingual minority schools, 2001: p.52).

By international instruments in the field of protection of minorities and obligations arising from the process of European integration, the Albanian government should commit to implementing and achieve the highest standards of respect and realization of the rights of national minorities and ethnolinguistic, living in Albania (L.Omari, The issue of national minorities and Albania, 2014: p. 280). All steps and initiatives to be undertaken will aim at full implementation of and compliance with the European Convention on Human Rights and the Framework Convention of the Council of Europe "On the Protection of National Minorities", ratified by Albania.

The rights of minorities in the Republic of Albania are enshrined in the constitution and some laws.

- The Constitution of the Republic of Albania in 1998 has defined minorities as an integral part of Albanian society, recognizing them all the rights, as well as other Albanian citizens.

- "Code of Administrative Procedure of the Republic of Albania", which states that in relation to private entities, public administration governed by the principle of equality in the sense that no one should be privileged or discriminated against because of race, religion, ethnicity language, political opinions, religious or philosophical beliefs, economic, education, social status or ancestry.

-"Penal Code of the Republic of Albania" This Code occupies a 
prominent place in the elimination of any kind of prejudice or discrimination against minorities and the protection of minorities living in Albania, as well as reporting of discriminatory acts against them (a number of provisions condemning "the violation of equality of citizens", "inciting hatred and racial, national or religious," the crime of genocide ", etc.

- "Code of Civil Procedure of the Republic of Albania," which provides for the use of the native language for people who do not know English at all stages of the trial and receive information on all the evidence and conduct of the trial through an interpreter.

- Law no. 9087, dated 19.06.2003, "The Electoral Code of the Republic of Albania", as amended by Law no. 9676, dated 01.13.2007. Albanian legislation guarantees the proper development of the elections and the participation of minorities in the electoral process.

- Law no.8580, dated 17.2.2000 "On Political Parties" guarantees the constitutional right to order the participation of minorities in public life.

Although the internal law of our country provides for a series of provisions in various laws that are aimed to protect the rights of minority political parties, all we see from this picture is the lack of a particular law on the rights of minorities (Minorities and protection of their rights in Albania, p. 32). Under these circumstances, protection of their rights remains fragmented and incomplete.

\section{The current problems of the rights of minorities in Albania in the framework of the European Commission's progress reports}

Albania, despite being a country with a complicated past has made progress in the improvement of a rule of law and democracy, with the signing of the Stabilization and Association Agreement (SAA) which since the entry into force has imposed obligations and commitments of Albania to approximate the Albanian legislation with the EU acquis. Efforts are quite large, as well as a collaboration between the parties in various areas of justice, the relations of neighborhood etc.

At the meeting of the Copenhagen of 1993, Council of Europe established a list of conditions that the countries of Central and Eastern Europe will need to meet to become members of the EU. Expressly determined that membership requires that the candidate country has achieved stability of institutions guaranteeing democracy, the rule of law, human rights and respect for and protection of minorities ").

After signing the SAA with the EU, Albania's obligations to implement the agreement in question are reflected in the progress reports of the European Commission annually in all fields, and in particular, "Human Rights and Protection of Minorities." Analysis of these progress reports indicates that there has been and continues to be a permanent commitment 
regarding continuous improvement of the standards of the protection and respect of human rights and fundamental freedoms, part of which are also minority rights. But with all the steps taken up in this period, the report submitted for 2007-2008 (Progress Report of the National Strategy "For the improvement of the living conditions of the Roma minority", December 2007) clarifies that the commitments made by Albania regarding the rights of minorities consisted of the implementation of the obligations arising from the Framework Convention on the Rights of Minorities, especially concerning the use of the minority language in relations with the authorities; establishment of traditional names and spread the education of minorities in their own language; implementation of the National Strategy for Roma and efforts to secure the necessary funds, as part of the Government's strategy for combating poverty and social exclusion; as part of the Government's strategy for the fight against poverty and social exclusion; also providing data about other minority groups in Albania.

All these obligations of the Albanian state were seen as a task to be carried out following with 2009 Report that noted: - Constitution guarantees the protection of civil, economic, social and political rights of minorities and the law prohibits the discriminatory treatment of any individual. Albania has three recognized national minorities (Greek, Macedonian and SerboMontenegrin) and two ethnolinguistic minorities (Aromanian and Roma) in Albania.

Albania has continued to develop the legal framework to (or "intending to") improve the implementation of the Framework Convention of the Council of Europe for the Protection of National Minorities. Agreements were signed between central and local authorities regarding the establishment of traditional names in minority languages. However, further efforts are needed to reduce inter-ethnic tensions that exist.

Regarding the Roma community are making efforts to improve their position, as well as institutional culture. However, remains problematic not having accurate data on minorities. Its solution will be achieved through a census, while respecting international standards for the protection of their data. The Civil Service Act provides for participation although these groups in public administration, the armed forces, and police. Efforts have been made to recruit persons belonging to minorities, particularly Roma, in the police.

In the 2010 Report its noted the growing media space problems affecting minorities, particularly the Roma minority (These findings have emerged from the monitoring done to the media. Also it was found in a survey conducted by AHC in 4 municipalities of the country, Tirana, Fier, Elbasan and Gjirokastra). It is first necessary for the media to pay attention to the promotion of minority tradition and culture. There are steps to amend 
the Law "On the Press", putting the minority media in the same conditions with the rest of the population.

Regarding the access of minorities in public administration until this year, from the Roma and Egyptian communities raised allegations of discriminatory treatment by the administration (These concerns were raised in a survey carried out by AHC in the Municipality of Tirana, Elbasan, Fier and Gjirokastra during September-November 2009 and on the tables developed by local actors in these districts over to the period FebruaryMarch 2010). In response to this complaint Albanian state has ample the elimination of all forms of discrimination in the administration of minority groups and encouraging them to participate in economic, cultural and social life in the country.

The adoption of "National Strategy for the protection of minorities" as the main objective had steps to take for the inclusion of Roma in police in those regions where they live, as well as the organization of seminars focusing on "Respect for human rights and particularly those of minorities. Although there is growing awareness of minority rights, knowledge of the administration in this field are scarce (These data are taken from the report that emerged from the survey conducted by AHC in Tirana, Elbasan, Fier ). In this context, it is first necessary government institutions for public administration that occasionally conducted training on their rights.

Some municipalities have begun to implement budgeting in consultation with stakeholders including in the way the minority groups (Elbasan city hall has implemented such a model: information taken from the meeting with municipal representatives and civil society, in February 2010).

Funding has been intended to promote handicraft products produced by Roma for domestic and foreign, also the Ministry of Culture, Youth and Sports supports various activities of minorities to maintain and develop their culture by financing projects submitted by an initiative of them. Until this year, the registration remains problematic situation in those districts where there has been the migration of Roma as Tirana and Durres, and for those in the community who emigrates in Greece (Study Report on the implementation of the recommendations of the report III of the European Commission against Racism and Intolerance (ECRI) and the obligations under the SAA). One of its main problems is the non-enrollment in the registry which has resulted in their inability to vote.

Ministry of Interior launched in 2011 a project to record the Roma, of whom about $50 \%$ had no identity cards. In the context of the general election, the Government issued identity cards for Roma. Another issue which requires attention and taking immediate measures by institutions is to prevent trafficking of Roma children, especially girls. The Albanian Government stresses that this trafficking is made in the context of traffic in 
general in human beings and not be based on ethnic groups or race for which the Albanian government has a particular strategy for the fight against trafficking in people.

In 2012 (European Commission Progress Report on Albania's 2012 Enlargement Strategy and Main Challenges for 2012-2013). The Albanian government took measures for the design of social policies, with the aim of poverty alleviation of Roma within existing possibilities of the Albanian state. This goal was achieved by supporting the Roma youth who finish school to be inserted in the labor market. Giving priority to the welfare of Roma families that meet the conditions provided by law for the benefit of this assistance.

Regarding the difficulties faced by members of minorities for restitution, the Albanian state created, and continuously is creating opportunities and space to the legal terms of the right to property for the entire population including minorities within the country.

The third opinion of the Advisory Committee on the Framework Convention for the Protection of National Minorities was published in June 2012 and recommended the adoption of a comprehensive legislation for minorities. The opinion aimed to help legal identity gaps legal fragmentation in this sector and clarification of state policy towards minorities, including the establishment of appropriate legal criteria for recognition of minorities and ensuring access and real rights for all minorities.

As regarding cultural rights; public education in minority languages is not yet available for all minority groups, and Albania has not adopted the European Charter for regional and minority languages.

In 2013 (European Commission Progress Report on Albania in 2013) the progress report noted that Albania should improve the living conditions of Roma rapidly, coordinating between central and local levels. For that Albania in the last progress report of the European Commission in 2014 and 2015 (European Commission Progress Report on Albania 2014 and 2015) has not had a positive evaluation after legal and policy framework needs yet improvement as regards the respect for and protection of minorities.

It is worth emphasizing that the importance that our country is giving the rights of minorities is heading towards a finalization of a comprehensive legal act. This is because the impulse that gives the approach and harmonization process of the acquis in our legislation regarding minority is an important aspect of protecting the rights and fundamental freedoms.

But remains an issue to discuss the implementation of comprehensive legal act so effectively to be an act of "reality" to the defense of their integration into the society where they live as minorities. 


\section{Conclusion}

International protection of minorities can support the Vienna Convention Framework Constitution, which does not provide collective minority rights exercised by the entirety of the minority group. This solution is explained by fears that such recognition could turn into a rigid support for the claims breakaway.

The Framework Convention specifies that persons belonging to national minorities may exercise both individually and together with others the rights and freedoms arising from the principles outlined in this Convention. Obligations that have been set are intended not only states to allow persons belonging to minorities to enjoy a freedom from which can benefit the rest of the population but require them to take measures including positive actions often of times to ensure the effectiveness of these rights. The reason is called the Framework Convention that implies the possibility that states translate the provisions of this Convention, based on the particular situation of their country, as well as appropriate legislation and appropriate government policy.

In the case of protection of minorities in the Albanian legislation we emphasize that the Albanian state in its historical evolutionary retrospective made progressive steps for the protection of minorities.

Based on the obligations in the framework of implementation of the SAA with EU, minorities make up a vital part of the respect for fundamental rights and freedoms and as such should be treated without discrimination by providing opportunities based on a particular legal act for minorities.

\section{References:}

V.Bici, "The issue of bilingual minority schools" Tirana: Publications "EMAL", 2001.

F. Benoit-Rohmer, "Minorities issue Europe, Tirana , 2007.

L. Omari "The issue of national minorities and OZ", Tirana: Publications "DUDAJ", 2014

A.Puto, "Public International Law" Tirana: Publications Dudaj, 2010

A.Puto, "Discussion on minorities, Tirana: publications "Dudaj, 2009

Minorities and protection of their rights in Albania, Albanian Center for Publication of human rights, Tirana: Morava publications, 2008

A. Boim Berxoli, Minorities in Albania , Tirana :"EMAL", 2005

Central State Archive; Fund: Ministry of Interior, 2007

Constitution of the Republic of Albania

The Framework Convention for the Protection of Minorities

European Convention for the Protection of Human Rights

International Covenant on Civil and Political Rights

Code of Administrative Procedure of the Republic of Albania 
Penal Code of the Republic of Albania"

Code of Civil Procedure of the Republic of Albania

Law no. 9087, dated 19.06.2003

Law no.8580, dated 17.2.2000

Annex II of the final document of the Vienna meeting

Progress Report of the National Strategy "For the improvement of the living conditions of the Roma minority", December 2007.

European Commission Progress Report 2008 Electoral Code of the Republic of Albania

European Commission Progress Report 2009

European Commission Progress Report on Albania 2010

Enlargement Strategy and Main Challenges for the period 2012-2013

European Commission Progress Report on Albania's 2013 Enlargement Strategy and Main Challenges 2013-2014

European Commission Progress Report on Albania's 2014 Enlargement Strategy and Main Challenges for the period 2014-2015, European Commission Progress Report on Albania of 2015, discharged in http://www.integrimi.gov.al/al/dokumente/progres-raporte/progres-raporti 